\title{
Comparative efficacy and toxicity of two vaccine candidates against Sporothrix schenckii using either Montanideтм Pet Gel A or aluminum hydroxide adjuvants in mice
}

\author{
Deivys Leandro Portuondo ${ }^{a}$, Alexander Batista-Duharte ${ }^{a}$, Lucas Souza Ferreira ${ }^{a}$, \\ Cleverton Roberto de Andrade ${ }^{\mathrm{b}}$, Camila Quinello ${ }^{\mathrm{a}}$, Damiana Téllez-Martínez ${ }^{\mathrm{a}}$, \\ Maria Luiza de Aguiar Loesch ${ }^{\mathrm{a}}$, Iracilda Zeppone Carlos ${ }^{\mathrm{a}, *}$ \\ a São Paulo State University (UNESP), School of Pharmaceutical Sciences, Department of Clinical Analysis, Araraquara, SP, Brazil \\ ${ }^{\mathrm{b}}$ São Paulo State University (UNESP), School of Dentistry, Department of Physiology E' Pathology, Araraquara, SP, Brazil
}

\section{A R T I C L E I N F O}

\section{Article history:}

Received 27 January 2017

Received in revised form 19 April 2017

Accepted 15 May 2017

Available online 4 July 2017

\section{Keywords:}

Sporothrix schenckii

Sporothrix brasiliensis

Aluminum hydroxide

Montanide $^{\mathrm{TM}}$ Pet Gel A

Cytotoxicity

Immunogenicity

Adjuvant

Vaccine

\begin{abstract}
A B S T R A C T
Sporotrichosis is an important zoonosis in Brazil and the most frequent subcutaneous mycosis in Latin America, caused by different Sporothrix species. Currently, there is no effective vaccine available to prevent this disease. In this study, the efficacy and toxicity of the adjuvant Montanide ${ }^{\mathrm{TM}}$ Pet Gel A (PGA) formulated with $S$. schenckii cell wall proteins (SSCWP) was evaluated and compared with that of aluminum hydroxide $(\mathrm{AH})$. Balb/c mice received two subcutaneous doses (1st and 14th days) of either the unadjuvanted or adjuvanted vaccine candidates. On the 21 st day, anti-ssCWP antibody levels (ELISA), the phagocytic index, as well as the ex vivo release of IFN- $\gamma$, IL-4, and IL-17 by splenocytes and IL-12 by peritoneal macrophages were assessed. Cytotoxicity of the vaccine formulations was evaluated in vitro and by histopathological analysis of the inoculation site. Both adjuvanted vaccine formulations increased antissCWP IgG, IgG1, IgG2a, and IgG3 levels, although IgG2a levels were higher in response to PGA +CWP100, probably contributing to the increase in S. schenckii yeast phagocytosis by macrophages in the opsonophagocytosis assay when using serum from PGA+CWP100-immunized mice. Immunization with $\mathrm{AH}+\mathrm{CWP100}$ led to a mixed Th1/Th2/Th17 ex vivo cytokine release profile, while PGA+CWP100 stimulated a preferential Th1/Th2 profile. Moreover, PGA+CWP100 was less cytotoxic in vitro, caused less local toxicity and led to a similar reduction in fungal load in the liver and spleen of S. schenckii- or S. brasiliensis-challenged mice as compared with AH+CWP100. These results suggest that PGA may be an effective and safe adjuvant for a future sporotrichosis vaccine.
\end{abstract}

(C) 2017 Elsevier Ltd. All rights reserved.

\section{Introduction}

Sporotrichosis is an emergent subcutaneous mycosis in tropical and subtropical regions, with isolated cases and outbreaks

\footnotetext{
Abbreviations: ssCWP, S. schenckii cell wall protein; AH, aluminum hydroxide; PGA, Montanide ${ }^{\mathrm{TM}}$ Pet GeL A; gp70, glycoprotein of $70 \mathrm{kD}$; NIS, serum from nonimmunized mice.

* Corresponding author at: São Paulo State University - UNESP, School of Pharmaceutical Sciences, Department of Clinical Analysis, Rodovia Araraquara-Jaú - km 1, 14800-903 Araraquara, SP, Brazil.

E-mail addresses: deivysleandro@gmail.com (D.L. Portuondo), batistaduhartea@ gmail.com (A. Batista-Duharte), gigabreath@hotmail.com (L.S. Ferreira), clevertonroberto72@gmail.com (C.R. de Andrade), caquinello@hotmail.com (C. Quinello),damianatellezm@gmail.com (D. Téllez-Martínez), ma_luizaloesch@ hotmail.com (M.L. de Aguiar Loesch), carlosiz@fcfar.unesp.br (I.Z. Carlos).
}

reported worldwide [1,2]. The disease is caused by different Sporothrix species, which are ubiquitous environmental saprophytes that can be isolated from soil and plant debris. In the environment, they can increase their virulence and cause infections to humans and other animals upon traumatic lesions with contaminated materials [3]. Over the last years, the zoonotic transmission of sporotrichosis through the bite or scratch of sick cats and other animals became an important cause of concern, mainly in Brazil [4,5].

Several pathogenic Sporothrix species have been described, including S. brasiliensis, S. globosa, S. mexicana, S. lurie, and S. schenckii sensu stricto [6]. In Brazil, the most frequently involved species in the cat-human zoonotic transmission is $S$. brasiliensis [5]. Sporotrichosis can assume many clinical forms, including fixed cutaneous or lymphocutaneous and disseminated forms, the latter 
of which has been mainly reported in immunocompromised individuals [6,7]. Given the renewed epidemiological importance of sporotrichosis and difficulties associated with the conventional antifungal drugs, different strategies are being investigated for prevention and treatment of this disease $[8,9]$.

Several immune mechanisms have been shown to play a role in resistance against S. schenckii [9-17], impelling the use of immunomodulation tools for the management of sporotrichosis. Previously, we studied two aluminum hydroxide (AH)-adsorbed $S$. schenckii cell wall proteins (ssCWP)-based vaccine formulations and demonstrated induction of a strong specific immune response in vaccinated mice [18]. Furthermore, sera from those mice conferred protection against $S$. schenckii infection after passive transference in non-vaccinated and non-infected mice. In that study, a local inflammatory reaction at the inoculation site of immunized mice was observed.

Local reactions and tumors at the inoculation site have been associated with alum-adjuvanted vaccines in genetically predisposed cats, ferrets, and dogs [19-22]. Montanide ${ }^{\mathrm{TM}}$ Pet Gel A (PGA) is a ready-to-disperse polymeric adjuvant designed to improve the safety and efficacy of vaccines for companion animals, especially in cats [23].

Considering the high prevalence of animal-to-human transmission and the predominance of the highly virulent species $S$. brasiliensis as the etiological agent in cats [5,24], the objective of this work was to compare PGA and AH regarding their safety and effectiveness in inducing a protective immune response against this species when formulated with ssCWP. This study will help us choose a better adjuvant for a future anti-Sporothrix veterinary vaccine.

\section{Materials and methods}

\subsection{Animals}

Male 5-7 week-old specific-pathogen-free (SPF) Balb/c mice were purchased from the Multidisciplinary Center for Biological Research (CEMIB), University of Campinas, São Paulo, Brazil. Five mice per group were housed in microisolator cages and maintained under SPF conditions. This work was approved by the Institutional Ethics Committee for Animal Use in Research (Protocol CEUA/FCF/ CAR 30/2012) and was in accordance with the National Institutes of Health Animal Care guidelines.

\subsection{Microorganism and growth conditions}

Sporothrix schenckii ATCC 16345 sensu stricto, isolated from a patient with diffuse lung infection (Baltimore, USA), and $S$. brasiliensis 250, isolated from a feline sporotrichosis case in Brazil, were kindly provided by the Oswaldo Cruz Foundation, Rio de Janeiro, Brazil. Mycelial-to-yeast conversion of both isolates was performed in $100 \mathrm{ml}$ of brain-heart infusion broth (Difco) for 7 days at $37^{\circ} \mathrm{C}$ with continuous agitation at $150 \mathrm{rpm}$ [15]. After that, an aliquot containing $2 \times 10^{7}$ or $2 \times 10^{5}$ yeasts from $S$. schenckii or $S$. brasiliensis, respectively, was transferred to a fresh medium and cultured for 5 more days at the same conditions.

\subsection{Extraction of ssCWP}

ssCWP extraction was performed as previously described [18].

\subsection{Adjuvants and vaccine formulation}

Aluminum hydroxide $(\mathrm{AH})$ gel adjuvant was bought from Invivogen (EUA); Montanide ${ }^{\mathrm{TM}}$ Pet Gel $\mathrm{A}$, an adjuvant composed of a highly stable dispersion of microspherical particles of sodium polyacrylate in water, was kindly provided by SEPPIC (France). The AH-ssCWPs formulation was prepared by mixing $0.1 \mathrm{mg}$ of ssCWPs with an amount of $\mathrm{AH}$ equivalent to $0.1 \mathrm{mg}$ of $\mathrm{Al}^{3+}$ ( $\left.\mathrm{AH}+\mathrm{CWP100}\right)$ in a total volume of $100 \mu \mathrm{l}$ and an adsorption time of $40 \mathrm{~min}$ [18]. The same antigen amount was formulated with 5\% PGA (PGA+CWP100), according to the manufacturer's instructions. In mice, the $0.1 \mathrm{mg}$ dose of $\mathrm{Al}^{3+}$ corresponds approximately to the maximum approved dose for human vaccines [25].

\subsection{In vitro cytotoxicity}

Mice were intraperitoneally (i.p) injected with $3 \mathrm{ml}$ of a $3 \%$ sodium thioglycollate (Difco) solution 3 days before euthanasia. Peritoneal cells were harvested, plated in 96 -well plates $\left(5 \times 10^{5}\right.$ cells/ml) in complete RPMI-1640 medium (cRPMI) and incubated overnight. Non-adherent cells were removed and macrophages were incubated with $100 \mu \mathrm{L}$ of cRPMI containing either CWP100, $\mathrm{AH}+\mathrm{CWP100}, \mathrm{PGA}+\mathrm{CWP100}, \mathrm{AH}\left(100 \mu \mathrm{g}\right.$ of $\left.\mathrm{Al}^{3+}\right)$, or $5 \% \mathrm{PGA}$ at $37^{\circ} \mathrm{C}$ in a $5 \% \mathrm{CO}_{2}$ atmosphere. cRPMI or $\mathrm{NaOH} 0.1 \mathrm{~N}$ were used as negative or positive controls, respectively. After $20 \mathrm{~h}$, cytotoxicity was determined using the MTT assay [26].

\subsection{Immunization schedule}

Balb/c mice $(n=5)$ received two subcutaneous (s.c) injections $(0.1 \mathrm{ml})$ on the back of the neck on days 0 and 14 with CWP100, $\mathrm{AH}+\mathrm{CWP100}$, PGA+CWP100, or PBS alone as negative control. Serum obtained 1 week after the second immunization was heatinactivated at $56^{\circ} \mathrm{C}$ for $30 \mathrm{~min}$, aliquoted and stored at $-20^{\circ} \mathrm{C}$ for further use.

\subsection{Serum antibody titration and opsonophagocytosis assay}

Both assays were conducted as described by Portuondo et al. [18]. Shortly, serum levels of anti-ssCWP IgG, IgG1, IgG2a and IgG3 were measured by ELISA. For the opsonophagocytosis assay, thioglycollate-elicited peritoneal macrophages were co-cultured in a 1:4 ratio with opsonized or non-opsonized S. schenckii yeasts in LabTek ${ }^{\circledR}$ slides (Nunc) for $2 \mathrm{~h}$ at $37^{\circ} \mathrm{C}$. After that, the slides were stained with Giemsa and phagocytic activity was expressed using the phagocytic index (mean number of phagocytosed yeasts per macrophage).

\subsection{Flow cytometry analysis}

Sporothrix brasiliensis yeasts obtained as described on item 2.2 and then washed thrice with $\mathrm{PBS}$ at $4^{\circ} \mathrm{C}$, were incubated at $37^{\circ} \mathrm{C}$ for $1 \mathrm{~h}$ with anti-ssCWP sera $(1 / 20)$ from AH+CWP100- or PGA+CWP100-immunized or non-immunized mice. After that, the yeasts were washed with PBS and incubated with FITCconjugated rabbit anti-mouse IgG (Sigma-Aldrich) (1/50) for $1 \mathrm{~h}$ at room temperature (RT). After washing, the binding of serum antibodies to the surface of the yeasts was determined using a flow cytometer (BD Accuri C6, BD Biosciences).

\subsection{Cytokine induction assay}

Thioglycollate-elicited peritoneal macrophages and total splenocytes were harvested from immunized mice and cultured in cRPMI for $24 \mathrm{~h}$ at $37^{\circ} \mathrm{C}$ and $5 \% \mathrm{CO}_{2}$ in the presence of ssCWPs. Final concentrations were $2.5 \times 10^{6}$ cells $/ \mathrm{ml}$ and $40 \mu \mathrm{g}$ of ssCWPs/ $\mathrm{ml}$ in cRPMI; concanavalin A $(0.25 \mu \mathrm{g} / \mathrm{ml})$ or Escherichia coli O111B lipopolysaccharide $(10 \mu \mathrm{g} / \mathrm{ml})$ were used as positive controls for macrophages or splenocytes, respectively; cRPMI alone was used as negative control. The following supernatant-accumulated 
cytokines were measured by ELISA (eBioscience) according to the manufacturer's instructions: IL-12, IFN- $\gamma$, IL-4, and IL-17.

\subsection{Protection assay}

Mice were immunized as described previously. Seven days after the second immunization, mice were i.p. challenged with $10^{6} \mathrm{~S}$. schenckii ATCC 16345 or S. brasiliensis 250 yeasts in $200 \mu \mathrm{l}$ of PBS. Protection was assessed by determining the number of colony forming units (CFUs) recovered from the spleen and liver of mice on day 5 post-infection when the peak of systemic fungal burden is expected $[15,18]$.

\subsection{Gross necropsy and histopathology}

The subcutaneous tissue and muscles where the vaccine formulation was inoculated were trimmed and preserved in $10 \%$ formalin according to the standardized methodology. Later, the paraffin embedded tissues were sectioned and stained with hematoxylin and eosin and examined using a light microscope. Relevant gross lesions were microscopically examined in all animals.

\subsection{Statistical analysis}

Data were analyzed using one-way analysis of variance (ANOVA) followed by Tukey's post-test using Graph Pad Prism 5. In this study, a $\mathrm{p}$ value of $<0.05$ was considered significant. The results are expressed as the mean $\pm \mathrm{SD}$.

\section{Results}

\subsection{In vitro cytotoxicity}

Cytotoxicity varied greatly between formulations, as follows, from most to least cytotoxic: $\mathrm{NaOH}$ (88.6\% $\pm 1.7 \%)$, $\mathrm{AH}(82.0 \% \pm 2.1 \%), \mathrm{PGA}(64.0 \% \pm 6.1 \%), \mathrm{AH}+\mathrm{CWP} 100(56.6 \% \pm 1.8 \%)$, PGA+CWP100 (40.2\% $\pm 2.1 \%)$, and CWP100 (20.4\% $\pm 3.6 \%)$ (Fig. 1). There was no significant difference between $\mathrm{AH}$ and $\mathrm{NaOH}$, or $\mathrm{AH}$

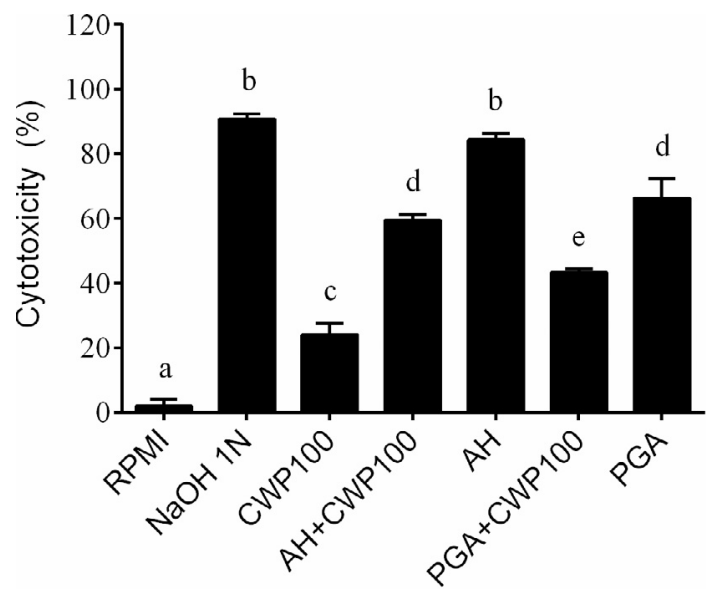

Fig. 1. In vitro cytotoxicity of the different vaccine formulations. Mice were intraperitoneally injected with $3 \mathrm{ml}$ of a $3 \%$ sodium thioglycollate aqueous solution. Three days post-inoculation, mice were euthanized and peritoneal exudate cells were harvested. The cells were incubated with cRPMI (negative control), $1 \mathrm{~N} \mathrm{NaOH}$ (positive control), PBS, CWP100, AH $\left(100 \mu \mathrm{g}\right.$ of $\left.\mathrm{Al}^{3+}\right), \mathrm{AH}+\mathrm{CWP100,} \mathrm{PGA}+\mathrm{CWP100}$, or $5 \%$ PGA and $20 \mathrm{~h}$ later cell viability was determined by the MTT assay. The results are presented as the mean \pm SD of three independent experiments and statistical significance was determined by one-way ANOVA using Tukey's multiple comparisons test and a 95\% confidence interval. Different letters represent significant differences ( $p<0.05)$ between treatments. CWP (cell wall proteins), AH (aluminum hydroxide), PGA (Montanide ${ }^{\mathrm{TM}}$ Pet Gel A).
+CWP100 and PGA alone. This result shows that PGA and AH-adsorbed antigens seem to inhibit cytotoxicity, as both $\mathrm{AH}+\mathrm{CWP} 100$ and PGA+CWP100 exerted significantly less cytotoxicity than the respective adjuvants alone. Furthermore, PGA was significantly less cytotoxic than $\mathrm{AH}$, alone or in formulation with the antigen, suggesting PGA is safer than $\mathrm{AH}$, at least in the context of this particular vaccine formulation.

\subsection{Antibody response and phagocytosis}

The PGA- or AH-adjuvanted formulations induced higher antissCWP IgG, IgG1, IgG2a, and IgG3 antibody levels as compared to CWP100 alone, whereas PGA+CWP100 induced significantly higher IgG2a levels than AH+CWP100 (Fig. 2A-D). In another set of experiments, we found that phagocytic activity was almost absent
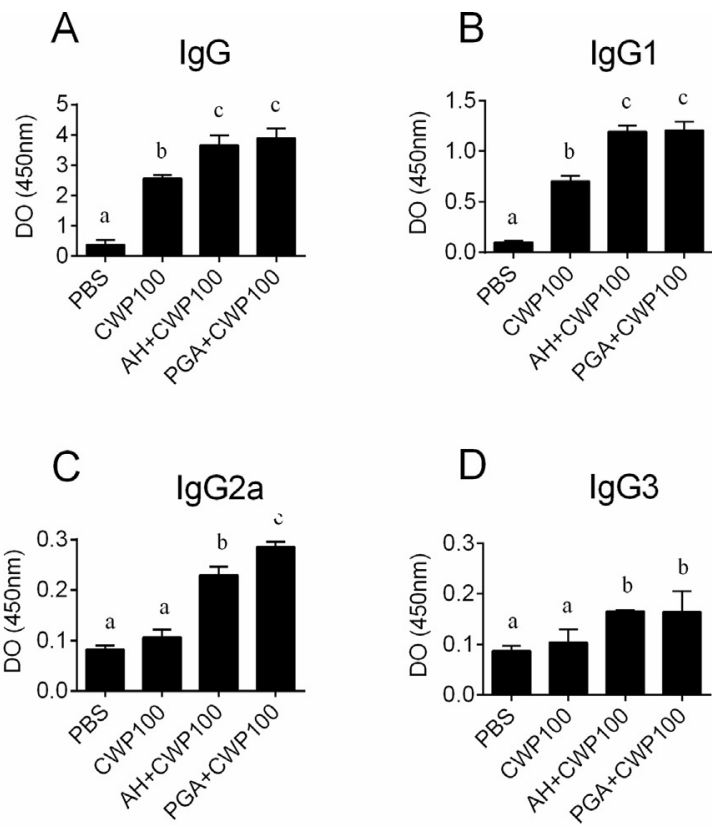

$E$
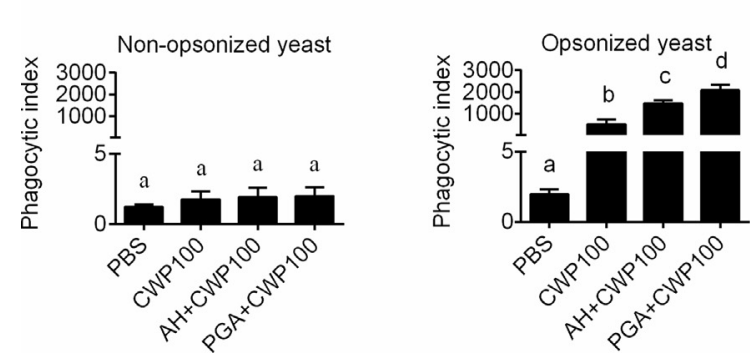

Fig. 2. Immunization with both the PGA- and AH-adjuvanted formulations markedly enhanced antibody response to ssCWPs which enhanced the phagocytic killing of $S$. schenckii yeasts. Balb/c mice $(n=5)$ were immunized (s.c.) twice with CWP100, AH+CWP100, PGA+CWP100, or PBS as negative control. Serum collected 7 days after the second immunization was used to determine ssCWP-specific IgC (A), IgG1 (B), IgG2a (C), and IgG3 (D) levels by ELISA or as opsonizing serum in the opsonophagocytosis assay. Thioglycollate-elicited peritoneal macrophages harvested from immunized mice were incubated with opsonized or PBS-treated $S$. schenckii yeasts (at a 1:4 macrophage to yeast ratio). (E and F) Phagocytic index (mean number of phagocytosed yeasts per macrophage) for non-opsonized or opsonized yeasts, as indicated. The results are presented as the mean \pm SD of 5 mice from one of three independent experiments and statistical significance was determined by one-way ANOVA using Tukey's multiple comparisons test and a $95 \%$ confidence interval. Different letters represent significant differences $(p<0.05)$ between treatments. 
in the presence of non-opsonized yeasts across all groups (Fig. 2E), but it was notably enhanced when yeasts were opsonized with serum from CWP100-, AH+CWP100-, or PGA+CWP100-vaccinated mice, but especially the latter (Fig. 2F).

\subsection{Flow cytometry}

Flow cytometry analysis revealed the presence of $S$. brasiliensis cross-reactive antibodies in the anti-ssCWP serum from $\mathrm{AH}+\mathrm{CWP100}$ - or PGA+CWP100- vaccinated mice (Fig. 3).

\subsection{Ex vivo cytokine induction}

Immunization with $\mathrm{AH}+\mathrm{CWP} 100$ or $\mathrm{PGA}+\mathrm{CWP} 100$ induced greater ex vivo release of IL-12 by macrophages and of INF- $\gamma$ by splenocytes (Fig. 4A and B) compared to CWP100 alone, although IL-12 levels were higher in response to PGA+CWP100 than AH+CWP100 (Fig. 4A). In contrast, immunization with $\mathrm{AH}+\mathrm{CWP100}$ led to greater ex vivo release of IL-4 and IL-17 by splenocytes compared with the other formulations (Fig. 4C and D). These results suggest PGA+CWP100 induces a Th1-biased cytokine profile and confirm the Th1/Th2/Th17 balanced profile in AH+CWP100-vaccinated mice previously described by Portuondo et al. [18].

\subsection{In vivo protection assay}

Five days after challenge with the fungi, the number of CFUs in spleen and liver was lower in AH+CWP100- and PGA+CWP100immunized mice compared to control mice (Fig. 5). No statistical difference was found between AH+CWP100- and PGA+CWP100immunized mice. Both ssCWP-based vaccine candidates provided protection against S. schenckii- or S. brasiliensis-challenge in mice.

\subsection{Histopathological assessment}

As expected, CWP100-immnunized mice showed no macroscopic lesions at the injection site (Fig. 6A). Nevertheless, microscopic evaluation showed a slight inflammatory response with
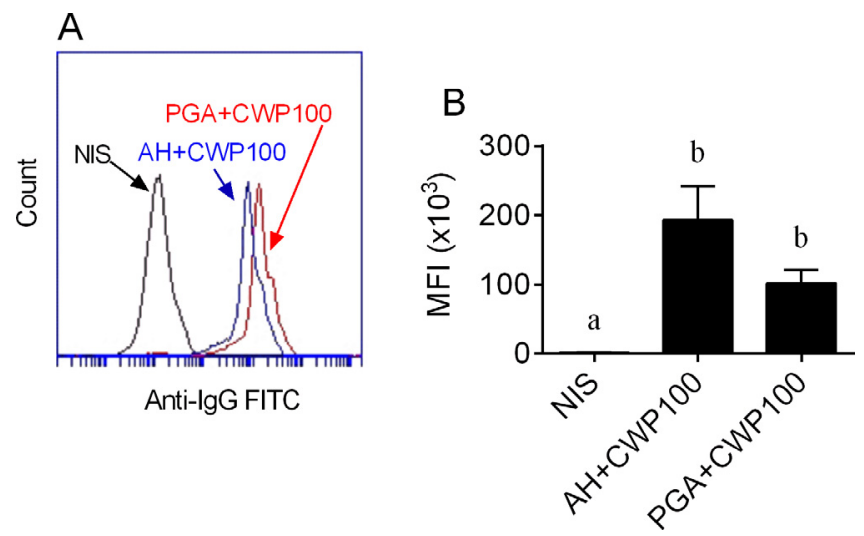

Fig. 3. Flow cytometry analysis showing the reactivity of the anti-ssCWP serum with S. brasiliensis yeasts. A S. brasiliensis Ss250 yeast suspension was previously incubated with anti-ssCWP serum obtained from Balb/c mice $(n=5)$ immunized (s.c.) twice with $A H+C W P 100$ or PGA+CWP100, or with serum from non-immunized mice (NIS). After washing, the cells were exposed to a FITC-conjugated rabbit anti-mouse IgG and analyzed using a flow cytometer. (A) Representative histogram from one independent experiment. (B) Median fluorescence intensity (MFI). The results are presented as the mean $\pm \mathrm{SD}$ of three independent experiments and statistical significance was determined by one-way ANOVA using Tukey's multiple comparisons test and a 95\% confidence interval. Different letters represent significant differences $(p<0.05)$ between treatments. CWP (cell wall proteins), AH (aluminum hydroxide), PGA (Montanide ${ }^{\mathrm{TM}}$ Pet Gel A). neutrophils, some striated muscle fiber degeneration, and subcutaneous edema (Fig. 6B-C). AH+CWP100 injection, on the other hand, produced palpable nodules at the injection site in all animals, varying in size between 1 and $5 \mathrm{~mm}$ (Fig. 6D) and microscopically characterized by an intense granulomatous reaction, abundant macrophages, neutrophils, and fibroblasts, as well as a loss of continuity in striated muscle fibers (Fig. 6E-F). In contrast, PGA+CWP100-injected animals showed no macroscopically visible nodules (Fig. 6G) but had a moderate inflammatory infiltrate with abundant macrophages and neutrophils upon microscopic evaluation (Fig. 6H and I).

\section{Discussion}

Robust adjuvant action is often associated with toxicity, which is influenced by direct interactions of the adjuvant/antigen formulation with the tissue at the inoculation site, causing an inflammatory reaction associated with systemic effects [21,27-29]. AH is a universally accepted adjuvant for human and veterinary vaccines and several experimental antifungal vaccines use $\mathrm{AH}$ in their composition [30]. However, growing concerns regarding efficacy and toxicity has stimulated the search for alternative adjuvants [27]. Here, AH was chosen as a "reference adjuvant" for comparison with PGA, a new polymeric adjuvant reported to have high safety and efficacy profiles, especially for companion animals [25,31]. We previously demonstrated that an AH-based vaccine formulation using purified ssCWPs was immunogenic and able to induce protective antibodies against this $S$. schenckii in mice [18]. However, most epidemic outbreaks in Brazil are associated with the zoonotic transmission of S. brasiliensis [5]. In light of this, we aimed to evaluate the comparative efficacy of two vaccine candidates in a
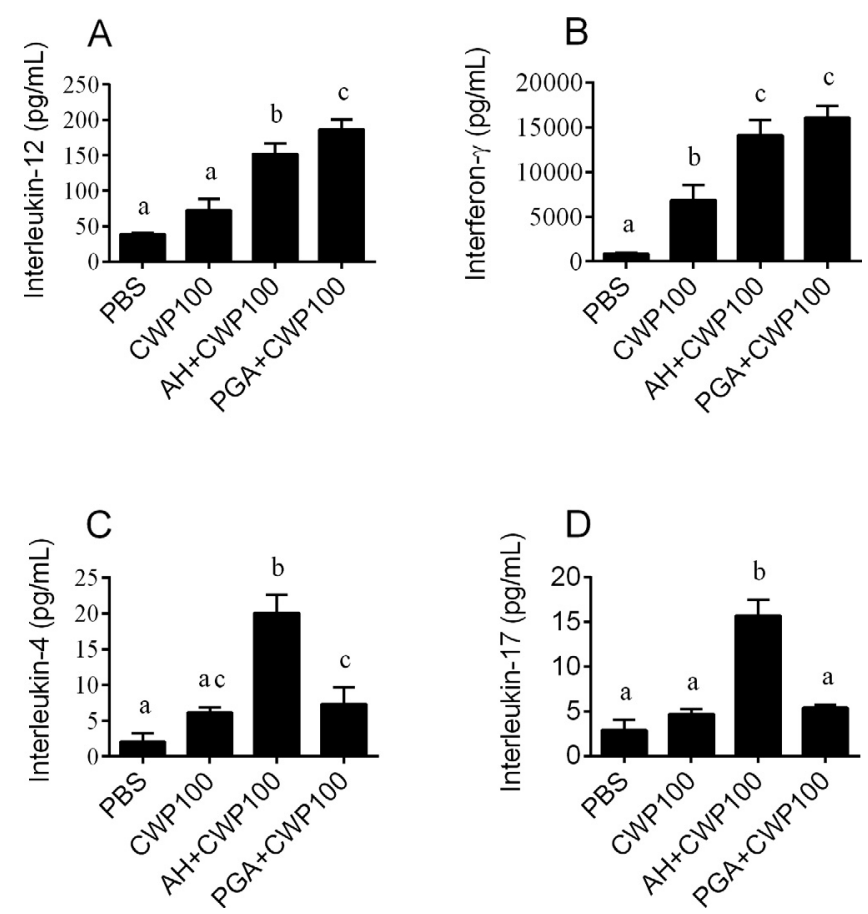

Fig. 4. Cytokine profile induced by vaccination with $A H+C W P 100$ or $P G A+C W P 100$. Ex vivo release of INF- $\gamma$ (A), IL-12 (B), IL-4 (C), or IL-17 (D) by ssCWP-stimulated splenocytes from vaccinated Balb/c mice $(n=5)$. The results are presented as the mean \pm SD of 5 mice from one of three independent experiments and statistical significance was determined by one-way ANOVA using Tukey's multiple comparisons test and a 95\% confidence interval. Different letters represent significant differences $(p<0.05)$ between each treatments. CWP (cell wall proteins), AH (aluminum hydroxide), PGA (Montanide ${ }^{\mathrm{TM}}$ Pet Gel A). 
A

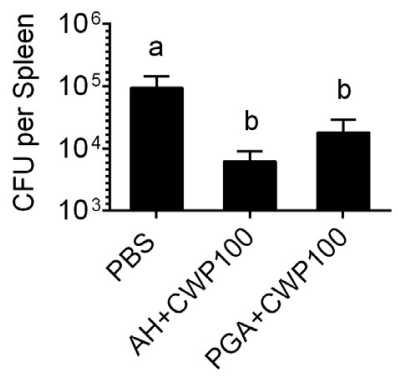

C
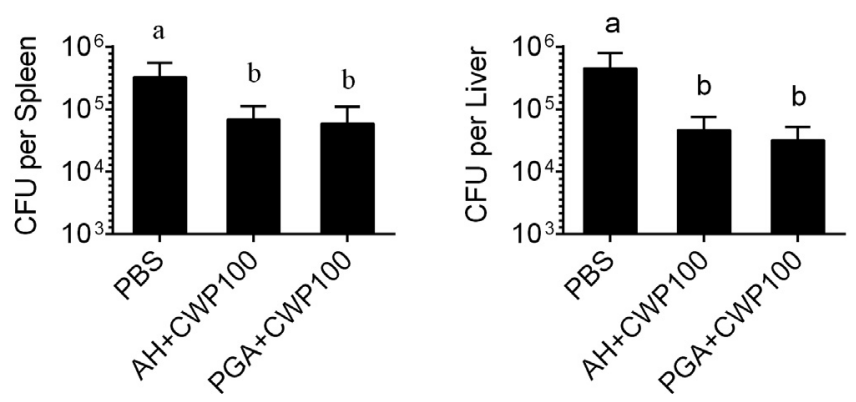

Fig. 5. Vaccination with $A H+C W P 100$ or $P G A+C W P 100$ was able to reduce the fungal burden. Balb/c mice $(n=5)$ were immunized (s.c.) twice with the indicated formulations. One week after the boost, mice were i.p. challenged with $S$. schenckii ATCC 16345 or S. brasiliensis Ss250 and five days after infection the protection was assessed by the number of CFUs recovered from the spleen and liver of mice. Fungal burden in the spleen (A) and liver (B) of S. schenckii-challenged mice. Fungal burden in the spleen (C) and liver (D) of $S$. brasiliensis-challenged mice. The results are presented as the mean \pm SD of 5 mice from one of three independent experiments and statistical significance was determined by one-way ANOVA using Tukey's multiple comparisons test and a 95\% confidence interval. Different letters represent significant differences $(\mathrm{p}<0.05)$ between treatments. CWP (cell wall proteins), AH (aluminum hydroxide), PGA (Montanide ${ }^{\mathrm{TM}}$ Pet Gel A).

model of experimental infection using both S. schenckii and $S$. brasiliensis.

A comparative evaluation of the in vitro cytotoxicity of $\mathrm{AH}$ and PGA, alone or formulated with the antigen was performed. Despite the high cytotoxicity exhibited by the adjuvants alone, when they were formulated with the antigen, occurred a significant reduction of toxicity, suggesting a protective effect against membrane damage owing to the presence of the antigen in the final formulation. A similar effect was observed on guinea pig erythrocytes when $\mathrm{AH}$ and calcium phosphate were pre-adsorbed with ovalbumin, drastically reducing the hemolytic effect exerted by both adjuvants alone [32], suggesting the antigen dose could be optimized to generate maximum efficacy and minimum toxicity in a given vaccine formulation. Our in vitro results matched the in vivo toxicity detected at the inoculation site. As expected, the $\mathrm{AH}$ formulation caused a granulomatous inflammatory response in the subcutaneous tissue while the PGA formulation caused only a mild local inflammatory response. Deville et al. [22] reported similar results in a comparative study between both adjuvants using different animal models. Together with the presence of abundant fibroblasts in the subcutaneous tissue of PGA+CWP100-immunized mice, these results suggest PGA formulations could be safer due to a faster recovery of the subcutaneous tissue. In another recent study using different adjuvants, the existence of a high correlation in the magnitude of the direct tisular irritation detected in the HET-CAM (hen's egg test on chorioallantoic membrane) model and in vivo local toxicity was demonstrated [33]. Our in vitro cytotoxicity assay using murine peritoneal macrophages showed a similar correlation with the in vivo toxicity at the inoculation site for both $\mathrm{AH}$ and PGA.

Several S. schenckii cell wall antigens are immunogenic. Nascimento et al. [34] reported that $S$. schenckii-infected mice develop a humoral response, particularly of the IgG1 and IgG3 subclasses, against gp70, a key immunodominant antigen of the $S$. schenckii cell wall. The relevance of this antigen was confirmed in a study where passive transference of IgG1 monoclonal antibodies (mAb) against gp70 (P6E7), before or during $S$. schenckii infection, caused a significant reduction in the number of CFUs in the spleen and liver of mice [35]. Another study also demonstrated that P6E7 was able to reduce the fungal burden in these organs in mice infected with virulent Sporothrix isolates, especially $S$. brasiliensis [36]. Moreover, opsonization of S. schenckii yeasts with PE67 led to increased phagocytosis and TNF- $\alpha$ production by macrophages [37]. As a whole, these studies evidence the protective effect of antigen-specific antibodies against both species. In a recent study, Alba-Fierro et al. [38] demonstrated the immunogenicity of an immunodominant $60 \mathrm{kDa}$ glycoprotein from the S. schenckii cell wall and suggested its potential in a vaccine candidate.

We previously showed that a serum containing mostly IgG1 and IgG2a antibodies, obtained from mice that had been immunized with a ssCWP-based $\mathrm{AH}$-adjuvanted vaccine candidate, conferred protection upon passive transference in mice [18]. Here, the PGAadjuvanted formulation induced a higher IgG2a level than the $\mathrm{AH}$ formulation. This could explain, at least in part, the higher phagocytic index obtained when S. schenckii yeasts were opsonized with serum from PGA+CWP100- as compared with AH+CWP100immunized mice. IgG2a antibodies are very effective in upregulating antibody responses, primarily via Fc-receptors and T cells [39]. Furthermore, the higher IgG2a levels induced by the PGA formulation suggest a Th1-prone response as IgG2a is regarded as a Th1-pattern subclass [40-42]. This was confirmed by the cytokine profile induced by the PGA formulation (i.e., high IL-12 and IFN $\gamma$ and low IL-4 levels). Maia et al. [43] showed a predominantly Th1 ex vivo cytokine release profile in the initial stages of infection and a Th2 predominance in later stages. Aligned with this, our group has previously shown the occurrence of M1 and M2 macrophages in the initial and late phase of the $S$. schenckii infection, respectively, matching this cytokine pattern [44]. M1 and M2 macrophages are stimulated by Th1 and Th2 cytokines, respectively [45].

Surprisingly, in this study the PGA formulation induced lower IL-17 levels than the AH formulation. Despite the recent findings indicating the importance of IL-17 to host resistance against $S$. schenckii [15], it seems the comparatively low induction of IL-17 by vaccination with the PGA formulation did not affect its effectiveness in our model. Some studies have shown that adjuvants from the Montanide ${ }^{\mathrm{TM}} \mathrm{Gel}$ line exert their immunoadjuvant effect through a similar mechanism to that of AH (i.e., by forming a depot at the injection site that favors antigen presentation and immune response induction). These adjuvants adsorb proteins on their surface, favoring the slow release of antigens, recruitment of inflammatory and antigen-presenting cells and therefore the induction of immune response $[22,31,46]$.

Conclusive evidence of protective immunity induction by the two vaccine candidates was found in the reduction of fungal load in the spleen and liver of vaccinated mice, which was similar for both candidates. Our results suggest that several mechanisms may be involved in the post-vaccinal protection conferred by the PGA formulation, including induction of opsonizing antibodies and an adequate balance of Th1 and Th2 cytokines. Further studies are necessary to ascertain the role played by these mechanisms, as well as others, in the post-vaccinal defense. 

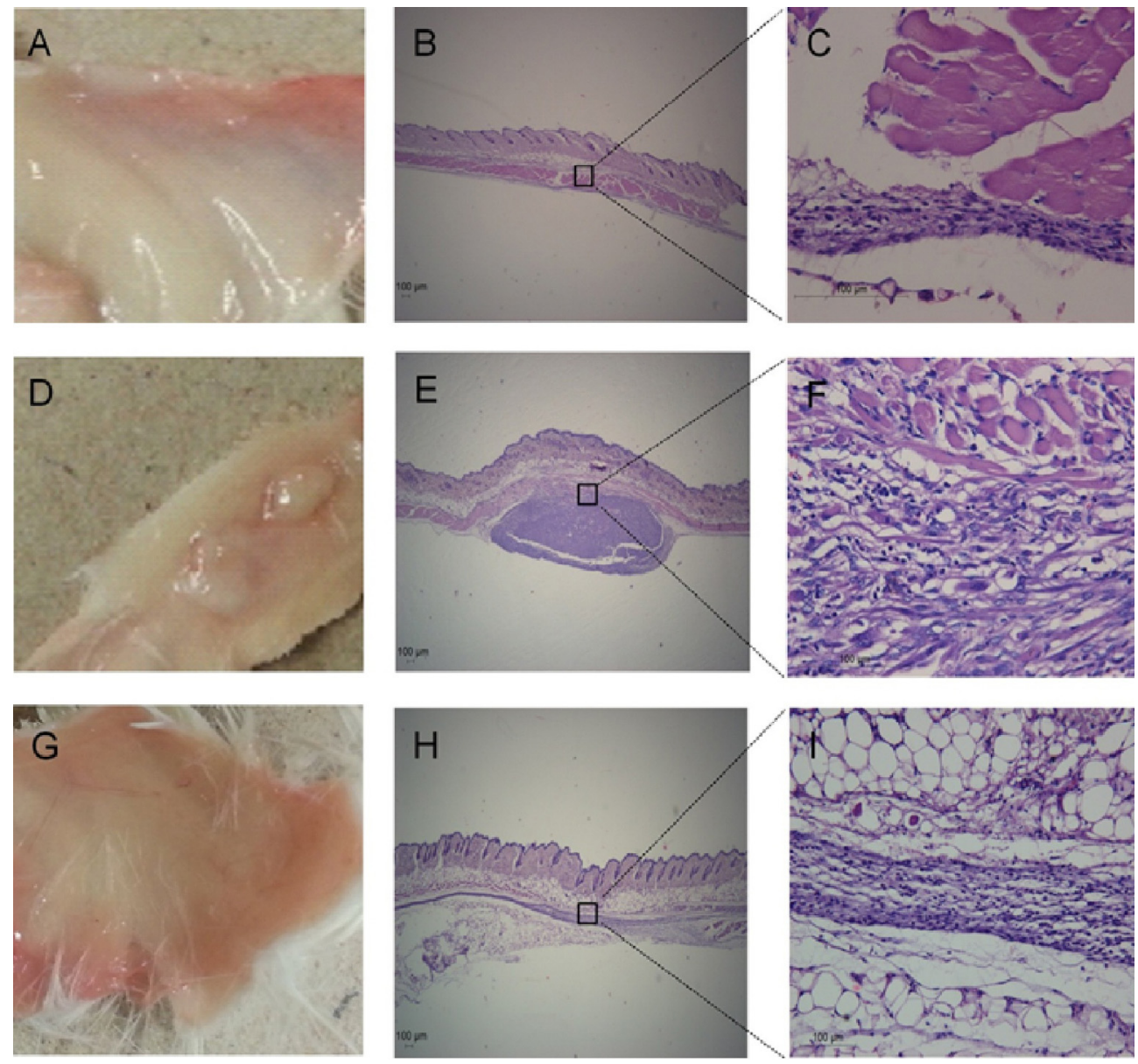

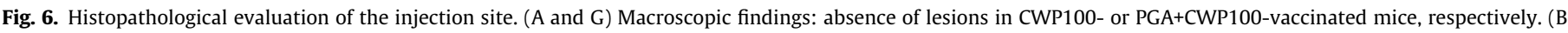

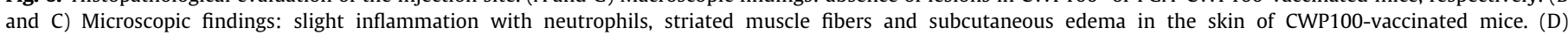

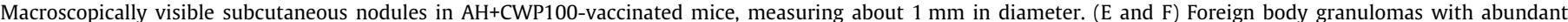

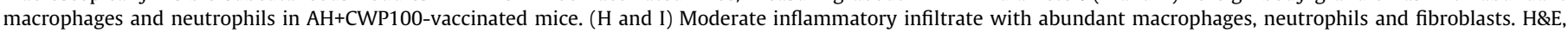
$2.5 \times$ and $20 \times$ magnification. CWP (cell wall proteins), AH (aluminum hydroxide), PGA (Montanide ${ }^{\mathrm{TM}}$ Pet Gel A).

Interestingly, an antigen from the low virulent $S$. schenckii ATCC 16345 strain [47] was able to confer protection against S. schenckii and $S$. brasiliensis, evidencing the existence of conserved immunodominant antigens between these species. Such cross-reactivity could prove beneficial for the simultaneous protection against many Sporothrix spp., besides offering useful information for the identification of conserved immunodominant antigens that could aid the development of a single multi-antigenic vaccine against Sporothrix infection. Moreover, using an antigen from a low virulent species contributes to reduce the risk of a hazardous contamination during the manufacturing process.

In conclusion, this study showed that PGA is able to confer the same level of protection as $\mathrm{AH}$ with the benefit of only minimal local reactions, making it a valuable alternative for a future antiSporothrix veterinary vaccine. Furthermore, the $S$. brasiliensis cross-reactivity could be useful for the multispecies immunoprophylaxis within the Sporothrix genus. Additional studies are needed to evaluate the effectiveness of this formulation in preventing infections caused by other Sporothrix species.

\section{Conflicts of interest}

The authors declare no commercial or financial conflict of interest.

\section{Acknowledgments}

The authors are grateful for the support granted by the Programa de Apoio a Estudantes Estrangeiros/AssociaÓĐo UniversitÃria Iberoamericana de Pœs-graduacĐo/Prœ-Reitoria de Pœs-graduacĐo da UNESP (PAEDEX/AUIP/PROPG). We are also grateful to Dr. Sandro Antonio Pereira from FundaÓĐo Oswaldo Cruz (Fiocruz) for providing the $S$. brasiliensis isolated used in this study.

\section{Appendix A. Supplementary material}

Supplementary data associated with this article can be found, in the online version, at http://dx.doi.org/10.1016/j.vaccine.2017.05. 04.

\section{References}

[1] Chakrabarti A, Bonifaz A, Gutierrez-Galhardo MC, Mochizuki T, Li S. Global epidemiology of sporotrichosis. Med Mycol 2015;53:3-14.

[2] Carlos IZ, Batista-Duharte A. Sporotrichosis: an emergent disease. In: Sporotrichosis. Springer International Publishing; 2015. p. 1-23.

[3] Téllez MD, Batista-Duharte A, Portuondo D, Quinello C, Bonne-Hernández R, Carlos IZ. Sporothrix schenckii complex biology: environment and fungal pathogenicity. Microbiology 2014;160:2352-65. 
[4] López-Romero E, del Rocío Reyes-Montes M, Pérez-Torres A, Ruiz-Baca E, Villa gómez-Castro JC, et al. Sporothrix schenckii complex and sporotrichosis, an emerging health problem. Future Microbiol 2011;6:85-102.

[5] Gremião ID, Menezes RC, Schubach TM, Figueiredo AB, Cavalcanti MC, Pereira SA. Feline sporotrichosis: epidemiological and clinical aspects. Med Mycol 2015;53:15-21.

[6] Rodrigues AM, de Melo Teixeira M, de Hoog GS, Schubach TM, Pereira SA, Fernandes GF, et al. Phylogenetic analysis reveals a high prevalence of Sporothrix brasiliensis in feline sporotrichosis outbreaks. PLoS Negl Trop Dis 2013;7(6):e2281.

[7] Moreira JA, Freitas DF, Lamas C. The impact of sporotrichosis in HIV-infected patients: a systematic review. Infection 2015:43:267-76.

[8] Batista-Duharte A, Pereira SA, Freitas DFS, Fuentes DP, Gutierrez-Galhardo MC, Carlos IZ. Therapeutic and prophylactic tools for sporotrichosis: current strategies and future tendencies. In: Sporotrichosis. Springer International Publishing; 2015. p. 147-77.

[9] Batista-Duharte A, Lastre M, Romeu B, Portuondo DL, Téllez-Martínez D, Manente FA, Carlos IZ. Antifungal and immunomodulatory activity of a novel cochleate for amphotericin B delivery against Sporothrix schenckii. Int Immunopharmacol 2016;40:277-87.

[10] Carlos IZ, da Graca Sgarbi DB, Angluster J, Alviano CS, Silva CL. Detection of cellular immunity with the soluble antigen of the fungus Sporothrix schenckii in the systemic form of the disease. Mycopathologia 1992;117:139-44.

[11] Sassá MF, Ferreira LS, de Abreu Ribeiro LC, Carlos IZ. Immune response against Sporothrix schenckii in TLR-4-deficient mice. Mycopathologia 2012;174:21-30.

[12] Negrini TD, Ferreira LS, Alegranci P, Arthur RA, Sundfeld PP, Maia DC, et al. Role of TLR-2 and fungal surface antigens on innate immune response against Sporothrix schenckii. Immunol Investigat 2013;42:36-48.

[13] Gonçalves AC, Maia DC, Ferreira LS, Monnazzi LG, Alegranci P, Placeres MC, et al. Involvement of major components from Sporothrix schenckii cell wall in the caspase-1 activation, nitric oxide and cytokines production during experimental sporotrichosis. Mycopathologia 2015;179:21-30.

[14] Maia DC, Gonçalves AC, Ferreira LS, Manente FA, Portuondo DL, Vellosa JC, et al. Response of cytokines and hydrogen peroxide to Sporothrix schenckii exoantigen in systemic experimental infection. Mycopathologia 2016;181:207-15.

[15] Ferreira LS, Goncalves AC, Portuondo DL, Maia DCG, Placeres MCP, BatistaDuharte A, et al. Optimal clearance of Sporothrix schenckii requires an intact Th17 response in a mouse model of systemic infection. Immunobiology 2015;220:985-92.

[16] Verdan FF, Faleiros JC, Ferreira LS, Monnazz LGS, Maia DCG, Tansine A, et al. Dendritic cell are able to differentially recognize Sporothrix schenckii antigens and promote Th1/Th17 response in vitro. Immunobiology 2012;217:788-94.

[17] Negrini TDC, Ferreira LS, Arthur RA, Alegranci P, Placeres MC, Spolidorio LC, et al. Influence of TLR-2 in the immune response in the infection induced by fungus Sporothrix schenckii. Immunol Investigat 2014;43:370-90.

[18] Portuondo DL, Batista-Duharte A, Ferreira LS, Martínez DT, Polesi MC, Duarte RA, et al. A cell wall protein-based vaccine candidate induce protective immune response against Sporothrix schenckii infection. Immunobiology 2016;221:300-9.

[19] Gupta RK, Relyveld EH, Lindblad EB, Bizzini B, Ben-Efraim S, Gupta CK. Adjuvants-a balance between toxicity and adjuvanticity. Vaccine 1993; $11: 293-306$.

[20] Hendrick MJ, Goldschmidt MH, Shofer FS, Wang YY, Somlyo AP. Postvaccinal sarcomas in the cat: epidemiology and electron probe microanalytical identification of aluminum. Can Res 1992;52:5391-4.

[21] Kass PH, Barnes Jr WG, Spangler WL, Chomel BB, Culbertson MR. Epidemiologic evidence for a causal relation between vaccination and fibrosarcoma tumorigenesis in cats. J Am Vet Med Assoc 1993;20:396-405.

[22] Batista-Duharte A, Portuondo D, Carlos IZ, Pérez O. An approach to local immunotoxicity induced by adjuvanted vaccines. Int Immunopharmacol 2013; 17:526-36.

[23] Deville S, Carneaux E, Bertrand F, Cauchard S, Cauchard J, Dupuis L. Adjuvant formulation for companion animals vaccines. Proc Vaccinol 2011;4:104-12.

[24] Montenegro H, Rodrigues AM, Dias MA, da Silva EA, Bernardi F, de Camargo ZP. Feline sporotrichosis due to Sporothrix brasiliensis: an emerging animal infection in São Paulo Brazil. BMC Veterinary Res 2014;10:269.

[25] Vecchi S, Bufali S, Skibinski DA, O'hagan DT, Singh M. Aluminum adjuvant dose guidelines in vaccine formulation for preclinical evaluations. J Pharma Sci 2012;101(1):17-20.

[26] Mosmann T. Rapid colorimetric assay for cellular growth and survival: application to proliferation and cytotoxicity assays. J Immunol Methods $1983 ; 65: 1-2$.
[27] O'Hagan DT, Fox CB. New generation adjuvants-from empiricism to rational design. Vaccine 2015;33:B14-20.

[28] Olafsdottir T, Lindqvist M, Harandi AM. Molecular signatures of vaccine adjuvants. Vaccine 2015;33:5302-7.

[29] Batista-Duharte A, Portuondo D, Perez O, Carlos IZ. Systemic immunotoxicity reactions induced by adjuvanted vaccines. Int Immunopharmacol 2014;20:170-80.

[30] Portuondo DLF, Ferreira LS, Urbaczek AC, Batista-Duharte A, Carlos IZ Adjuvants and delivery systems for antifungal vaccines: current state and future developments. Med Mycol 2015;53:69-89.

[31] Cauchard S, Bertrand F, Barrier-Battut I, Jacquet S, Laurentie M, Barbey C, et al Assessment of the safety and immunogenicity of Rhodococcusequi-secreted proteins combined with either a liquid nanoparticle (IMS 3012) or a polymeric (PET GEL A) water-based adjuvant in adult horses and foals-Identification of promising new candidate antigens. Veterinary Immunol Immunopathol 2014;157:164-74.

[32] Kato H, Shibano M, Saito T, Yamaguchi J, Yoshihara S, Goto N. Relationship between hemolytic activity and adsorption capacity of aluminum hydroxide and calcium phosphate as immunological adjuvants for biologicals. Microbiol Immunol 1994;38:543-8.

[33] Batista-Duharte A, Murillo GJ, Pérez U, Tur EN, Portuondo DF, Martínez BT, et al. The Hen's Egg test on chorioallantoic membrane an alternative assay for the assessment of the irritating effect of vaccine adjuvants. Int J Toxicol 2016;35:627-33.

[34] Nascimento RC, Almeida SR. Humoral immune response against soluble and fractionate antigens in experimental sporotrichosis. FEMS Immunol Med Microbiol 2005;43:241-7.

[35] Nascimento RC, Espindola NM, Castro RA, Teixeira PA, Loureiro, Penha CV, et al. Passive immunization with monoclonal antibody against a $70-\mathrm{kDa}$ putative adhesin of Sporothrix schenckii induces protection in murine sporotrichosis. Eur J Immunol 2008;38:3080-9.

[36] de Almeida JRF, Kaihami GH, Jannuzzi GP, de Almeida SR. Therapeutic vaccine using a monoclonal antibody against a 70-kDa glycoprotein in mice infected with highly virulent Sporothrix schenckii and Sporothrix brasiliensis. Med Mycol 2015;53:42-50.

[37] de Lima Franco D, Nascimento RC, Ferreira KS, Almeida SRD. Antibodies against Sporothrix schenckii enhance TNF- $\alpha$ production and killing by macrophages. Scandinavian J Immunol 2012;75:142-6.

[38] Alba-Fierro CA, Pérez-Torres A, Toriello C, Pulido-Camarillo E, López-Romero E Romo-Lozano Y, et al. Immune response induced by an immunodominant 60 $\mathrm{kDa}$ glycoprotein of the cell wall of Sporothrix schenckii in two mice strains with experimental sporotrichosis. J Immunol Res 2016;6:52-5831.

[39] Getahun A, Dahlström J, Wernersson S, Heyman B. IgG2a-mediated enhancement of antibody and $\mathrm{T}$ cell responses and its relation to inhibitory and activating Fc $\gamma$ receptors. J Immunol 2004;172:5269-76.

[40] Sörman A, Zhang, Ding Z, Heyman B. How antibodies use complement to regulate antibody responses. Mol Immunol 2014;61:79-88.

[41] Germann T, Bongartz M, Dlugonska H, Hess H, Schmitt E, Kolbe L, et al. Interleukin-12 profoundly up-regulates the synthesis of antigen-specific complement-fixing IgG2a, IgG2b and IgG3 antibody subclasses in vivo. Eur J Immunol 1995;25:823-9.

[42] Lefeber DJ, Benaissa-Trouw B, Vliegenthart JF, Kamerling JP, Jansen WT, Kraaijeveld K, et al. Th1-directing adjuvants increase the immunogenicity of oligosaccharide-protein conjugate vaccines related to Streptococcus pneumoniae type 3. Infect Immun 2003;71:6915-20.

[43] Maia DCG, Sassa MF, Placeres MCP, Carlos IZ. Influence of Th1/Th2 cytokines and nitric oxide in murine systemic infection induced by Sporothrix schenckii. Mycopathologia 2006;16:11-9.

[44] Alegranci P, de Abreu Ribeiro LC, Ferreira LS, de Cássia Negrini T, Maia DCG Tansini A, et al. The predominance of alternatively activated macrophages following challenge with cell wall peptide-polysaccharide after prior infection with Sporothrix schenckii. Mycopathologia 2013;176:57-65.

[45] Bagheri M, Dong Y, Ono M. Molecular diversity of macrophages in allergic reaction: comparison between the allergenic modes; Th1-and-Th2-derived immune conditions. Iranian J Allergy, Asthma Immunol 2015;14:261-72.

[46] Vialle R, Dupuis L, Deville S, Bertrand F, Gaucheron J, Aucouturier J. Microgel particulate adjuvant: characterization and mechanisms of action. Proc Vaccinol 2010;2:12-6.

[47] Almeida-Paes R, De Oliveira LC, Oliveira MME, Gutierrez-Galhardo MC Nosanchuk JD, Zancopé-Oliveira RM. Phenotypic characteristics associated with virulence of clinical isolates from the Sporothrix complex. BioMed Res Int 2015:1-10. 